\title{
Arctic-Alpine species in the bryoflora of the Altai-Sayan mountain region
}

\author{
Olga Pisarenko* \\ Central Siberian Botanical Garden SB RAS, 630090 Novosibirsk, Russia
}

\begin{abstract}
In the bryoflora the Altai-Sayan mountain region, 125 species have a predominantly Arctic-alpine distribution. A table of the locations geo-coordinates and habitat types in EUNI terms is compiled. The most common and rare species have been identified. The peculiarities of ecology and distribution of the species are discussed.
\end{abstract}

\section{Introduction}

In non-tropical Eurasia, the moss species diversity is the highest in oceanic and mountain regions [1]. In the bryoflora of the Ob River basin (author's calculations), only 6\% of species are not recorded in the mountains; and about $40 \%$ of the bryoflora species grow almost exclusively in the mountains and are not found or rare on the plain of Western Siberia. It was shown that in the mountains of South Siberia, in each altitude belt the most numerous is a group of mosses which occur throughout the whole height profile [2]; herewith the number of species decreases from the forest belt to the highlands. There are relatively few species whose distribution in the mountains is limited to the highlands. For example, in the Eastern Sayan, there are only 6\% of species are restricted to the upper vegetation belt, goltsy belt [2]. Similarly, in the bryoflora of the Salair-Kuznetsk region [3], only 25 from 395 species ( 6\%) are associated exclusively with highlands. But mosses are small in size and can find suitable microhabitats in different environments; single finds in atypical conditions are not rare in the case of mosses. To analyze the patterns of distribution and ecology of species, it is necessary to take into account the occurrence of species in different ecotopes and altitude zones.

At the generalization of bryological materials for the territory of the former Soviet Union, about 100 mosses were assigned to the group of species of the Arctic-alpine distribution [1]. Since that time, the list of Russian bryoflora has changed significantly: more than 300 species have been added and over 50 species have been excluded [4].

The main area of my research for many years has been the Salair, the Kuznetsk Highlands, some ridges of the Republic of Altai and the Republic of Tuva. All these territories belong to the Altai-Sayan mountain region (ASMR). The article aims to analyze the current information on the composition, distribution and ecology of Arctic-Alpine species for the western part of the ASMR (west of the Yenisei River).

\footnotetext{
*Corresponding author: o_pisarenko@ mail.ru
} 


\section{Materials and methods}

Own and literary data [5] on ASMR mosses as well as database "Herbarium specimens of mosses of Russia" [6] materials are analyzed. A preliminary list of ASMR bryoflora is compilated firstly, then species occurring exclusively or mainly in high-mountain and in the Arctic (subarctic) regions were selected. Recently described/recognized species, the distribution of which remains unclear, do not take into account. A table of the locations geo-coordinates is compiled for these species; the table includes 2143 records. Visualization of the species localities is in QGis18.5.3. Habitats of the species are also taken into account and encoded by Eunis [7].

\section{Results and discussion}

The list of species occurring exclusively or mainly in high-mountain and in the Arctic (subarctic) regions includes 125 taxa. That is about 20\% of ASMR bryoflora.

Fifteen the most common are Andreaea rupestris Hedw., Aulacomnium turgidum (Wahlenb.) Schwägr., Bartramia ithyphylla Brid., Brachythecium erythrorrhizon Bruch et al., Dicranum elongatum Schleich. ex Schwägr., Dicranum flexicaule Brid., Dicranum spadiceum J.E.Zetterst., Grimmia funalis (Schwägr.) Bruch et al., Grimmia incurva Schwägr., Grimmia reflexidens Müll.Hal., Hymenoloma crispulum (Hedw.) Ochyra, Lescuraea saxicola (Bruch et al.) Molendo, Myurella julacea (Schwägr.) Bruch et al., Paludella squarrosa (Hedw.) Brid., Tortula hoppeana (Schultz) Ochyra; they are widespread in the highlands throughout the region.

Many of the Arctic-Alpine species are known in ASMR from single separate localities; the rarest species are Amblyodon dealbatus (Hedw.) P.Beauv., Andreaea alpina Hedw., A. heinemannii Hampe \& Müll.Hal., Aongstroemia julacea (Hook.) Mitt., Arctoa fulvella (Dicks.) Bruch, Schimp. \& W. Gümbel, Cnestrum alpestre (Wahlenb. ex Huebener) Nyholm ex Mogensen, Cratoneuron curvicaule (Jur.) G.Roth, Encalypta brevipes Schljak., E. longicolla Bruch, Grimmia caespiticia (Brid.) Jur., G. donniana Sm., G. fuscolutea Hook., G. mollis Bruch, Schimp. \& W. Gümbel, G. triformis Carestia \& De Not., Hygrohypnum alpestre (Hedw.) Loeske, H. norvegicum (Bruch et al.) J.J.Amann, Mnium blyttii Bruch, Schimp. \& W. Gümbel, Oligotrichum hercynicum (Hedw.) DC., Orthodontium lignicola (Broth.) D.C. Zhang, Plagiobryum demissum (Hook.) Lindb., Pohlia obtusifolia (Vill. ex Brid.) L.F.Koch, Polytrichastrum altaicum Ignatov \& G.L. Merr., P. septentrionale (Brid.) E.I. Ivanova, N.E. Bell \& Ignatov, Psilopilum laevigatum (Wahlenb.) Lindb., Timmia austriaca Hedw., Tortula cernua (Huebener) Lindb., T. laureri (Schultz) Lindb., Voitia nivalis Hornsch. The distribution of some of them is mapped in supplementation of the author's materials (Fig. 1).

The group of Arctic-Alpine species is not homogeneous in ecological terms. In the EUNIS system, the habitats occupied by species are assigned to 10 categories of 2-3 levels (Fig. 2). (Most species can grow in several types of habitats, so the total percentage on the histogram exceeds $100 \%$ ). The largest number of species is associated with rocky habitats (H3); but only some of them are obligate petrophytes (Andreaea spp., Bucklandiella, Coscinodon cribrosus (Hedw.) Spruce, Grimmia spp., Hymenoloma crispulum, Lescuraea spp., Schistidium spp.), others grow on fine soil in crevices and can be found on soil outcrops in tundra (Bartramia ithyphylla, Distichium inclinatum (Hedw.) Bruch, Schimp. \& W.Gümbel , Encalypta alpina Sm., Encalypta longicolla, Isopterygiella alpicola (Lindb.) Ignatov \& Ignatova, Myurella julacea, Racomitrium lanuginosum (Hedw.) Brid., Tortula hoppeana et al.). Different tundra and alpine and subalpine scrubs (F1.1. + F1.2 + F2) are the next habitat type by species number - besides mentioned, Aulacomnium turgidum, Brachythecium turgidum (Hartm.) Kindb., Dicranum spp., Stegonia latifolia (Schwägr.) 
Venturi ex Broth. and others take place there. Groups of species associated with nival habitats (E4.2) and high-mountaines streams $(\mathrm{C} 2+\mathrm{C} 3)$, mires (D) and are approximately equal in volume; examples E4.2 - Kiaeria starkei (F.Weber \& D.Mohr) I.Hagen, Pohlia drummondii (Müll.Hal.) A.L.Andrews, P. obtusifolia, Polytrichum sexangulare (Flörke ex Brid.) G.L.Sm., Oligotrichum hercynicum; C2\&C3 - Amblyodon dealbatus Grimmia mollis, Oncophorus virens (Hedw.) Brid., Paludella squarrosa, Schistidium agassizii Sull. \& Lesq.; D - Loeskypnum badium (Hartm.) H.K.G.Paul, Meesia triquetra (Jolycl.) Angstr., M. uliginosa Hedw., Paludella squarrosa, Pseudocalliergon trifarium (F.Weber \& D.Mohr) Loeske, P. turgescens (T.Jensen) Loeske, Warnstorfia pseudosarmentosa (Cardot \& Ther.) Tuom. \& T.J. Kop.

The rest are: Orthodontium lignicola grows only in Siberian cedar woodlands near timberline (G3.1); Pohlia andrewsii A.J.Shaw and Psilopilum laevigatum were collected in similar communities; Brachythecium erythrorrhizon is common on alpine meadows (E4.1).

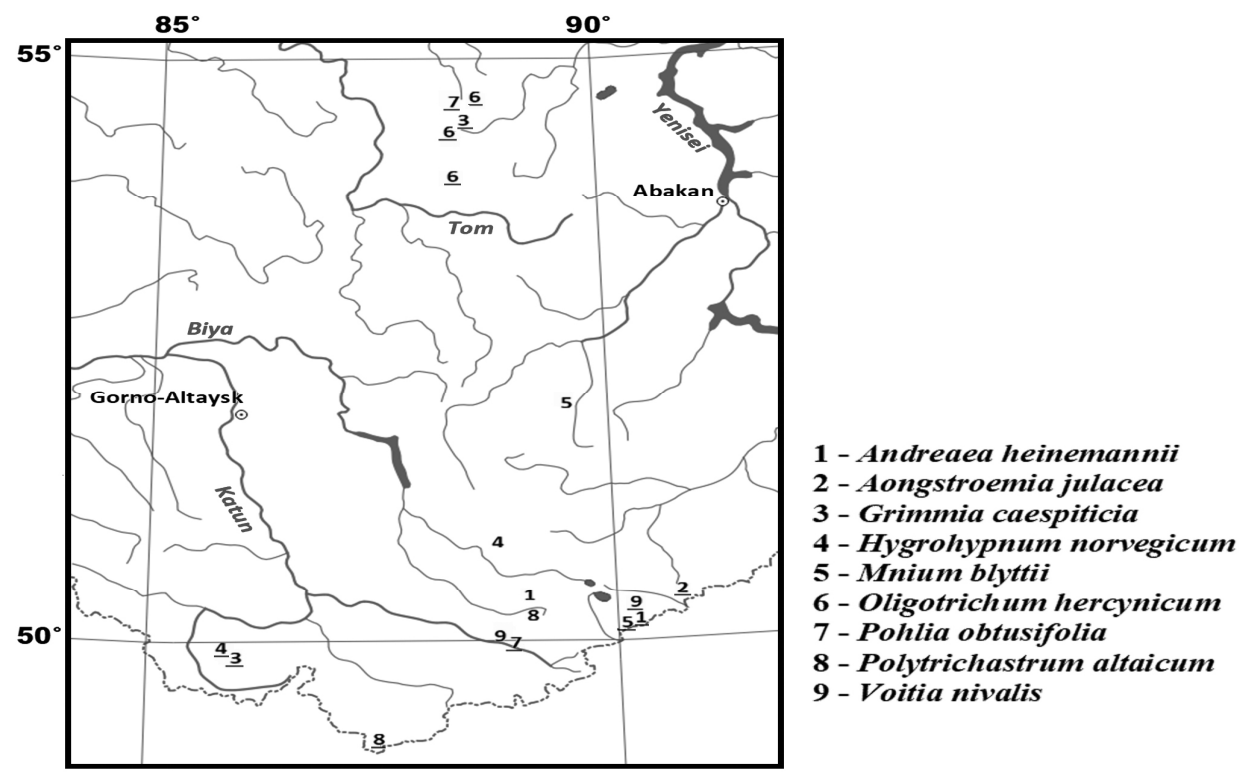

Fig. 1. Localities (numbered) of some rare Arctic-Alpine species in the west part of the Altai-Sayan mountain region. The points of the author's findings are underlined.

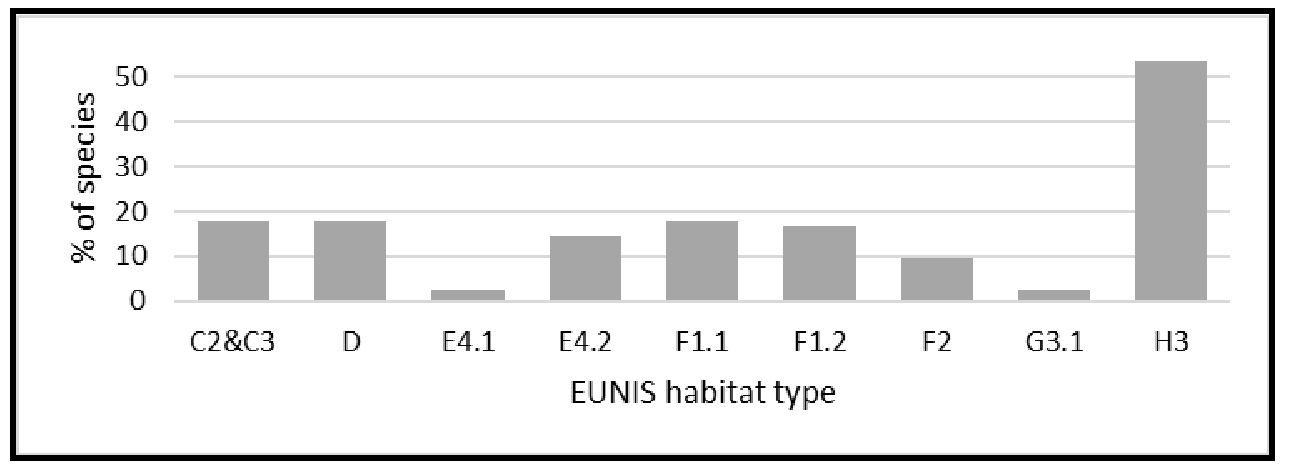

Fig. 2. Distribution of Arctic-Alpine species in the west part of the Altai-Sayan mountain region by EUNIS habitat type 
Under special conditions, some Arctic-Alpine species descend in the mountains to the low altitudes. So, at 450-600 m altitude isolated finds are known for Andreaea rupestris, Blindia acuta (Hedw.) Bruch, Schimp. \& W. Gümbel, Cyrtomnium hymenophyllum (Bruch, Schimp. \& W. Gümbel) Holmen, Grimmia unicolor, Hymenoloma crispulum, Oncophorus virens, Orthothecium chryseon Bruch, Schimp. \& W. Gümbel, Plagiobryum zieri (Hedw.) Lindb., Pohlia andrewsii, Pohlia longicolla (Hedw.) Lindb., Timmia austriaca.

In addition to the difference in occupied habitats, Arctic-Alpine species are differentiated by their attraction to bioclimatic sectors. Earlier it was shown through bioclimatic modeling in Maxent, that the potential area of Aulacomnium turgidum in ASMR covers the highlands of the semihumid and humid sectors; whereas the potential area of Stegonia latifolia encompasses the semiarid sector - the highlands of the SouthEast Altai and the South Tuva [8]. This trend can be traced to a whole series of species. One would notice that, Lescuraea incurvata (Hedw.) E.Lawton and Racomitrium lanuginosum occur mainly in semihumid and humid sectors (Fig. 3, b, d); the same about Bucklandiella sudetica (Funck) Bednarek-Ochyra \& Ochyra., Grimmia reflexidens, Syntrichia norvegica F.Weber. In contrary, Pseudocalliergon turgescens and Distichium inclinatum are restricted by semiarid sector (Fig. 3, a, c); the same about Catoscopium nigritum (Hedw.) Brid., Amblyodon dealbatus, Voitia nivalis.
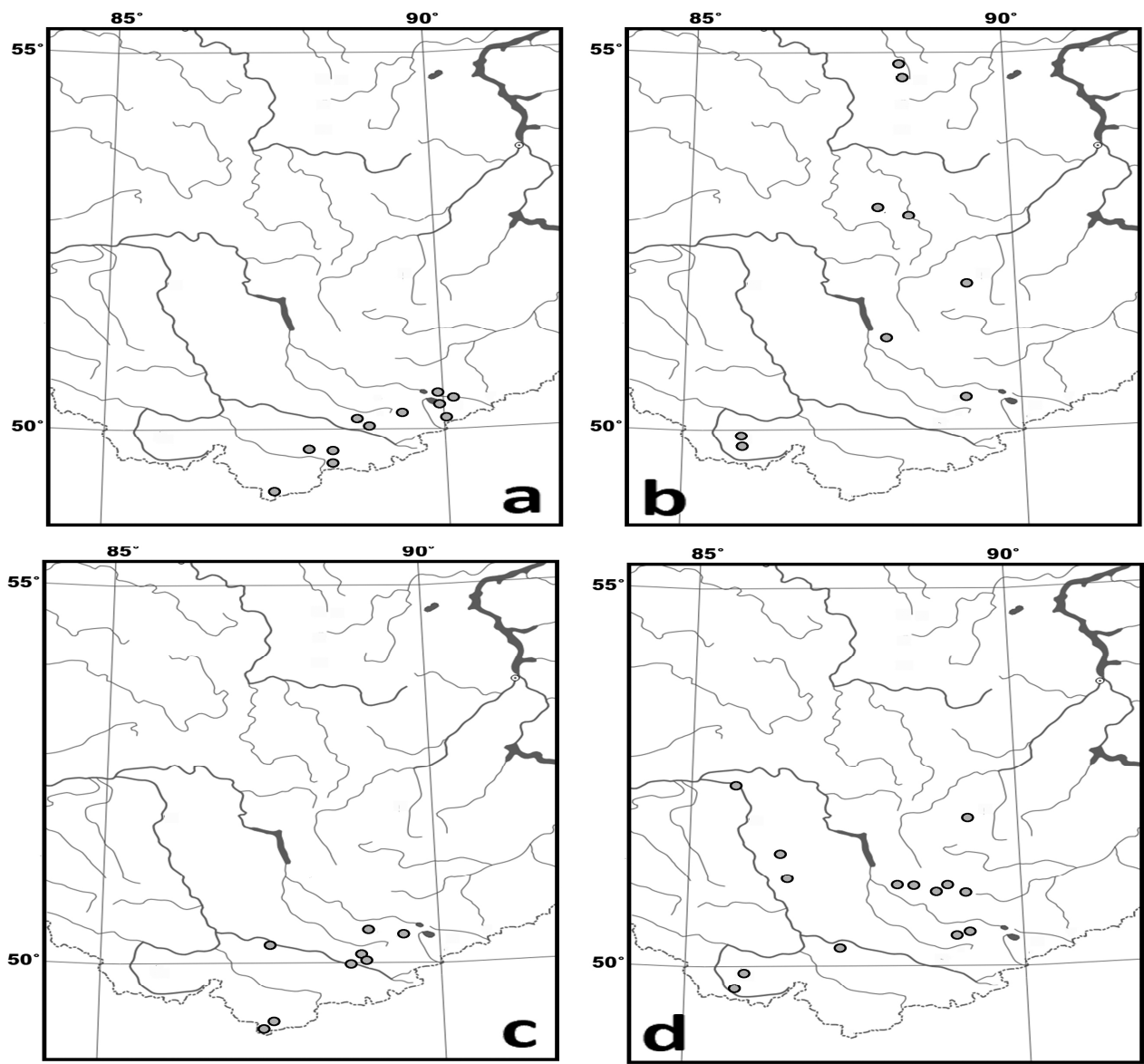

Fig. 3. Localities (numbered) of some rare Arctic-Alpine species in the west part of the Altai-Sayan mountain region: a - Pseudocalliergon turgescens; b - Lescuraea incurvata; c - Distichium inclinatum; $\mathbf{d}$ - Racomitrium lanuginosum. 
The differentiation of species by bioclimatic sectors cannot be explained by the peculiarities of their ecology: for instance, Stegonia latifolia grows in rather dry Dryastandra, but Catoscopium nigritum occur along a streams, and Pseudocalliergon turgescens leaves in mires. Historical reasons obviously determine this phenomenon.

Extremely rare some Arctic-Alpine species occur in the plain; these habitats are relict and often associated with mire massifs. The most amazing of these formations in adjacent plains is the mire between the Krasnoe and Kokui settlements in the Kemerovo region (N $54^{\circ} 35 \square$; E $\left.85^{\circ} 22 \square\right)$; Cinclidium stygium Sw., Meesia triquetra, Pseudocalliergon trifarium, Scorpidium cossonii (Schimp.) Hedenäs, Scorpidium scorpioides (Hedw.) Limpr. grow here.

The research was carried out at the expense of a grant from the Russian Science Foundation № 18-14-00121, https://rscf.ru/project/18-14-00121. I thank Ministry of Science and Higher Education of Russia for support of CCU "Herbarium MBG RAS"; author's samples are in biocollection USU 440537.

\section{References}

1. M. S. Ignatov, Arctoa 2(1993)

2. L. V. Bardunov, Mosses of the Eastern Sayan (Leningrad, Nauka, 1965).

3. O. Yu. Pisarenko, Arctoa 23 (2014)

4. O. V. Ivanov, M. A. Kolesnikova, O. M. Afonina et al., Arctoa 26 (2017)

5. O. Yu. Pisarenko, Plant world of Asian Russia, 39(3) (2020)

6. Herbarium specimens of Russian mosses http://arctoa.ru/Flora/basa.php

7. EUNIS https://eunis.eea.europa.eu/habitats-code-browser.jsp

8. O. Yu. Pisarenko, N. I. Makunina, BIO Web of Conferences 24 (2020) 